\title{
Honey bee viruses in Serbian colonies of different strength
}

\author{
Dragan Cirkovic ${ }^{1}$, Jevrosima Stevanovic \\ Jelena Aleksic ${ }^{5}$, Zoran Stanimirovic ${ }^{2}$ \\ 1 Department of Chemical and Technological Sciences, State University of Novi Pazar, Novi Pazar, Serbia \\ Department of Biology, Faculty of Veterinary Medicine, University of Belgrade, Belgrade, Serbia \\ 3 Department of Parasitology, Faculty of Veterinary Medicine, University of Belgrade, Belgrade, Serbia \\ 4 Department of Economics and statistics, Faculty of Veterinary Medicine, University of Belgrade, Belgrade, Serbia \\ 5 Institute of Molecular Genetics and Genetic Engineering (IMGGE), University of Belgrade, Beograd, Serbia \\ Corresponding Author: Jevrosima Stevanovic \\ Email address: rocky@vet.bg.ac.rs
} Uros Glavinic $^{2}$, Nevenka Aleksic ${ }^{3}$, Spomenka Djuric ${ }^{4}$,

Protection of honey bees is of great economic importance because of their role in pollination. Crucial steps towards this goal are epidemiological surveys of pathogens connected with honey bee losses. In this study deformed wing virus (DWV), chronic bee paralysis virus (CBPV), acute bee paralysis virus (ABPV) and sacbrood virus (SBV) were investigated in colonies of different strength located in five regions of Serbia. The relationship between colony strength and virus occurrence/infection intensity were assessed as well as the genetic relationship between virus sequences from Serbia and worldwide. Real-time RT-PCR analyses detected at least one virus in $87.33 \%$ of colonies. Single infection was found in $28.67 \%$ colonies $(21.33 \%, 4.00 \%, 2.67 \%$ and $0.67 \%$ in cases of DWV, ABPV, SBV and CBPV, respectively). In the majority of colonies (58.66\%) more than one virus was found. The most prevalent was DWV (74\%), followed by ABPV, SBV and CBPV $(49.30 \%, 24.00 \%$ and $6.70 \%$, respectively). Except for DWV, the prevalence of the remaining three viruses significantly varied between the regions. No significant differences were found between colony strength and either (i) the prevalence of DWV, ABPV, SBV, CBPV and their combinations, or (ii) DWV infection levels. The sequences of honey bee viruses obtained from bees in Serbia were 93-99\% identical with those deposited in GenBank. 


\section{Honey bee viruses in Serbian colonies of different strength}

2

3 Running title: Apis mellifera viruses in Serbia

4

5 Dragan Cirkovic $^{1}$, Jevrosima Stevanovic ${ }^{2}$, Uros Glavinic ${ }^{2}$, Nevenka Aleksic ${ }^{3}$, Spomenka Djuric ${ }^{5}$, 6 Jelena Aleksic ${ }^{4}$, Zoran Stanimirovic ${ }^{2}$

7

$8{ }^{1}$ Department of Chemical and Technological Sciences, State University of Novi Pazar, Novi

9 Pazar, Serbia

10 2Department of Biology, Faculty of Veterinary Medicine, University of Belgrade, Belgrade,

11 Serbia

$12{ }^{3}$ Department of Parasitology, Faculty of Veterinary Medicine, University of Belgrade, Belgrade, 13 Serbia

14 4Institute of Molecular Genetics and Genetic Engineering (IMGGE), University of Belgrade,

15 Belgrade, Serbia

$16{ }^{5}$ Department of Economics and Statistics, Faculty of Veterinary Medicine, University of

17 Belgrade, Belgrade, Serbia

Corresponding author:

Jevrosima Stevanovic

E-mail: rocky@,vet.bg.ac.rs

Dragan Cirkovic and Zoran Stanimirovic contributed equally to this work. 
33 Abstract

34 Protection of honey bees is of great economic importance because of their role in pollination. Crucial steps towards this goal are epidemiological surveys of pathogens connected with honey bee losses. In this study deformed wing virus (DWV), chronic bee paralysis virus (CBPV), acute bee paralysis virus (ABPV) and sacbrood virus (SBV) were investigated in colonies of different strength located in five regions of Serbia. The relationship between colony strength and virus occurrence/infection intensity were assessed as well as the genetic relationship between virus sequences from Serbia and worldwide. Real-time RT-PCR analyses detected at least one virus in $87.33 \%$ of colonies. Single infection was found in $28.67 \%$ colonies $(21.33 \%, 4.00 \%, 2.67 \%$ and $0.67 \%$ in cases of DWV, ABPV, SBV and CBPV, respectively). In the majority of colonies $(58.66 \%)$ more than one virus was found. The most prevalent was DWV (74\%), followed by ABPV, SBV and CBPV (49.30\%, 24.00\% and 6.70\%, respectively). Except for DWV, the prevalence of the remaining three viruses significantly varied between the regions. No significant differences were found between colony strength and either (i) the prevalence of DWV, ABPV, SBV, CBPV and their combinations, or (ii) DWV infection levels. The sequences of honey bee viruses obtained from bees in Serbia were 93-99\% identical with those deposited in GenBank.

\section{Introduction}

Honey bees (Apis mellifera) are well-known beneficial insects for their popular products, and much more for their important role in pollination (Venturini et al., 2017). Unfortunately, huge 
61 losses of managed honey bee colonies were reported worldwide (van Engelsdorp et al., 2008;

62 van Engelsdorp et al., 2009, Bacandritsos et al., 2010; van Engelsdorp et al., 2012; Lee et al., 2015; Antúnez et al., 2016; Kulhanek et al., 2017; Brodschneider et al., 2018), but no single factor was confirmed to be a certain cause of colony mortality (van Engelsdorp et al., 2009), although the mite Varroa destructor and associated viruses have most often been cited (Francis, Nielsen \& Kryger, 2013; McMenamin \& Genersch, 2015; Steinhauer et al., 2018). More than 22 honey bee viruses have been identified and described so far (Genersch, 2010;),

90 which exist or co-exist in individual bees or colonies, but may remain unnoticed (Chen \& Siede, 2007; Brutscher, McMenamin \& Flenniken, 2016). However, several viruses transferred by $V$. destructor considered to pose increasing risk to colonies' health (Martin et al., 2012) including deformed wing virus (DWV), chronic bee paralysis virus (CBPV), acute bee paralysis virus (ABPV) and the sacbrood virus (SBV), all of them seeming to have worldwide occurrence and distribution (Genersch, 2010; Simeunović et al., 2014a; Brutscher, McMenamin \& Flenniken, 2016).

In Southeastern Europe, the presence and prevalence of bee viruses have been investigated in Hungary, Slovenia and Croatia (Bakonyi et al., 2002; Forgách et al., 2008; Toplak et al., 2012; Tlak Gajger et al., 2014; Tlak Gajger, Bičak \& Belužić, 2014). In Serbia, four honey bee viruses were reported: ABPV, Egypt bee virus J strain (EBV), cloudy wing virus (CWV) and the black queen cell virus (BQCV) by Kulinčević, Ball \& Mladjan (1990), and DWV and ABPV by Simeunović et al. (2014a). However, due to the lack of information on the prevalence of SBV and CBPV, as well as the long time which passed since the previous investigations necessity demands newer research.

There is limited information about the relation between colony strength and presence of bee viruses.

The present study was aimed at (1) surveying the prevalence of DWV, SBV, ABPV and CBPV in honey bee colonies of different strength in Serbia; (2) exploring the differences between virus prevalence/intensity of infection and colony strength; (3) phylogenetic analyses to reveal the relationship between viruses found in Serbia and those deposited in GenBank. 
92 One hundred and fifty colonies were sampled from 32 apiaries (approximately five colonies per 93 apiary) located in five administrative regions of Serbia (Fig. 1) in autumn (in period from 94 September 25 to October 5) 2017.

95 On each apiary two strong, one medium and two weak colonies were chosen. Colony strength 96 assessment and classification were done as in Cavigli et al. (2016). The selected colonies were 97 without visible signs of any disease. About a hundred workers, both foragers and house bees were chosen for each sample, placed in sterile test tubes on dry ice, and stored at $-20^{\circ} \mathrm{C}$ until being processed.

Thirty randomly selected specimens taken from each bee sample were pulverized and homogenized in $5 \mathrm{~mL}$ of PBS solution. After centrifugation, from $140 \mu \mathrm{L}$ of the supernatant the RNA was extracted with ZR Viral RNA Kit ${ }^{\mathrm{TM}}$ (Zymo Research, Orange, CA).

The obtained sequences were amplified in Rotor-Gene Q 5plex (Qiagen, Germany) and the target viruses detected with the Rotor-Gene Probe RT-PCR Kit (Qiagen, Germany), in separate singlestep reactions. The primer pairs and probes for DWV, ABPV and SBV (Table 1) were the same as used by Chantawannakul et al. (2006) and for CBPV those deployed by Blanchard et al. (2007). The final primer concentration $800 \mathrm{nM}$ and probe concentration of $400 \mathrm{nM}$ proved optimum. The analyses were done in conditions defined in the work of Simeunović et al. (2014a). With each set of sample reactions standard dilutions of the control sample were run and a threshold level set according to the standard curve obtained.

Selected RNA isolates were subjected to endpoint RT-PCRs using primer pairs and following the recommendations from ANSES (2011). The sequencing of each amplicon was done in both orientations in ABI 3130 Genetic Analyzer (Applied Biosystems, USA).

The obtained partial nucleotide (nt) sequences of honeybee viruses were identified by the BLAST search (http://blast.ncbi.nlm.nih.gov/Blast.cgi) against the GenBank database.

Sequences encoding a partial coding sequence (cds) of polyprotein gene of DWV, a capsid protein gene of ABPV, a partial cds of RNA-dependent RNA polymerase (RdRp) gene of CBPV, and a partial cds of polyprotein gene of SBV were recovered. They were used for phylogenetic analyses along with related sequences deposited in GenBank. The best models of sequence evolution according to the Bayesian Information Criterion assessed MEGA version 6 (Tamura et al., 2007) were as follows: T92 + G for DWV and SBV, T92 + I for ABPV, and K2 + G + I for 
123 CBPV. Evolutionary relations assessed using these models of sequence evolution and the

124 Neighbor-Joining (NJ) algorithm were shown as phylograms. Statistical support was tested with

1251000 nonparametric bootstrap (BS) replicates, with $50 \% \geq \mathrm{BS} \leq 74 \%$ considered moderate

126 support, and $\mathrm{BS} \geq 75 \%$ considered good support

127

128 Statistical analysis

129 Depending on data characteristics (testing for normality), the results were presented through the 130 mean and standard deviation, or the median and interquartile range were used. Differences were 131 tested using ANOVA, t-test, or, where appropriate, non-parametric Mann-Whitney U test and 132 Kruskal-Wallis test. Pearson chi-square analysis (or Fisher's exact test) were applied where 133 necessary. Data analysis was performed using IBM SPSS Statistics ver. 21.0 software (IBM, 134 USA).

135

136

137

\section{Results}

138

139

140

141

142

143

144

145

146

147

148

149

150

151

152

153
All of the four viruses in examined samples of adult bees were detected. Their prevalence differed depending on the region of sampling (Fig. 1). In 150 honey bee samples (colonies), the prevalence of these four viruses was as follows: 74\% of DWV, $49.30 \%$ of ABPV, $24.00 \%$ of SBV and $6.70 \%$ of CBPV. Samples negative for all four viruses comprised $12.67 \%$ of the colonies investigated (Fig. 2).

In $87.33 \%$ of samples analysed at least one virus was detected. Single infection was found in $28.67 \%$ of colonies (DWV, ABPV, SBV and CBPV in $21.33 \%, 4.00 \%, 2.67 \%$ and $0.67 \%$ colonies, respectively, Table 2$)$. The majority of colonies $(58.66 \%)$ were found to be infected with more than one virus. DWV had the highest prevalence in all regions (66.70-83.30\%), while the least prevalent virus was CBPV (0-19\%). Except for DWV, the prevalence of the remaining three viruses was significantly different between different regions ( $\chi 2$ test: DWV $P=0.554$, ABPV $P=0.001$, SBV $P<0.001$, CBPV $P=0.030$ ).

The prevalence of each virus in weak, medium and strong colonies is shown in Fig. 3. DWV was most prevalent in strong colonies (78\%), followed by weak (72.90\%) and medium colonies (68.80\%). The highest number of ABPV-positive samples was recorded in medium colonies $(62.50 \%)$, followed by strong (49.20\%) and weak colonies (42.40\%). SBV was found in $25.40 \%$ 
154 of weak colonies, $25.00 \%$ of medium ones and in $22.00 \%$ of strong colonies. CBPV were found

155 in $9.40 \%$ of medium colonies, $8.50 \%$ weak and $3.40 \%$ strong colonies. No significant differences

156 were recorded in the prevalence of DWV, ABPV, SBV and CBPV infections (and their

157 combinations) between weak, medium and strong colonies were recorded with the $\chi 2$ test (Fig.

158 3). The significance of differences in virus infection levels (expressed through Ct values)

159 between colonies of different strength were also tested. In order to avoid any confounding factor

160 originated from the presence of other viruses in multiple infections, only single infections were

161 taken into consideration in the data analysis. The numbers of samples with single ABPV, SBV

162 and CBPV infections were not statistically valid for the comparison of their Ct values in strong,

163 medium and weak colonies; therefore, only DWV infection intensity was eligible for testing in

164 respect to colony strength. No significant differences were found between DWV infection levels

165 in colonies of different strength (Fig. 4; ANOVA, $F=0.681, P=0.513$ ). In addition, the results

166 presented in Fig. 5 show that DWV Ct values significantly differ between single DWV infection

167 and double infections caused by DWV and ABPV, SBV or CBPV (ANOVA, $F=7.510$,

$168 P<0.001)$.

169

170

Phylogenetic analyses

171

172 Phylogenetic trees showing evolutionary relations between Serbian and worldwide honeybee 173 viruses DWV, ABPV, SBV and CBPV are shown in Figs. 6-9, respectively.

174 Nine DWV sequences detected in Serbian honeybees were deposited in GenBank: Serbia D1

175 (GenBank Access. No. KM001902); Serbia D2 (Access. No. KM001903); Serbia D3 (Access.

176 No. KM001904); Serbia D4 and D5 (Access. No. KM001905, these two sequences were

177 identical and thus they were deposited in the GenBank under the same accession number); Serbia

178 D6 (Access. No. KM001906); Serbia D7 (Access. No. KM001907); Serbia D8 (Access. No.

179 KM001908); and Serbia D9 (Access. No. KM001909). BLAST search found 99 to 98\%

180 nucleotide identities with DWV sequences in the database. Eighteen additional DWVs sequences

181 from the GenBank were used for phylogenetic analysis, and VDVs (AY251269 and JF440525)

182 were used as outgroups to root the tree. The length of the aligned matrix was $420 \mathrm{nt}$.

183 Evolutionary relations of studied DWVs are shown in Fig. 6. Five Serbian DWVs organized into 
184 two moderately supported clusters, comprising three and two sequences, respectively, were 185 closely related to DWVs from the United Kingdom, while others were dispersed throughout the 186 tree.

187 Two Serbian ABPV sequences, KL4 and KL5, were identical, and thus, they were deposited in 188 the GenBank under the same accession number, KM001899. They showed 97 to $93 \%$ nucleotide 189 identities to ABPV sequences in the database. Ten additional European ABPV sequences from 190 the GenBank were used for phylogenetic analysis, and KBV (AY452696) was used as outgroup 191 to root the tree shown in Fig. 7. The length of the aligned matrix was 398 nt. Serbian ABPVs 192 were closely related to the Hungarian ones while Western and Northern European viruses formed 193 separate clusters.

194 Three identical Serbian SBV sequences, S1, KL2 and KL25, deposited in the GenBank under the same accession number, KM001901, showed 99 to 94\% sequence identity rates with other SBVs in the database. Seventeen additional SBVs from the GenBank were used for phylogenetic analysis. The length of the aligned matrix was $570 \mathrm{nt}$, and the recovered tree is shown in Fig. 8 . Three Serbian SBVs cluster together with SBVs from the continental Europe.

Two identical Serbian CBPV sequences, CBPV-1 and CBPV-3 deposited in the GenBank under the same accession number, KM001900, show 96 to 93\% sequence identity with other CBPVs in the GenBank. The length of the aligned matrix comprising Serbian and ten additional CBPVs was $429 \mathrm{nt}$. The relations of studied CBPVs are shown in Fig.9.

\section{Discussion}

In the era of intensive agriculture and serious decline in pollinator populations worldwide, primarily honey bees (Goulson et al., 2015), it is of great importance to gain an insight into the distribution and prevalence of factors most often connected with bee losses in any geographic region (van Engelsdorp et al., 2008; van Engelsdorp et al., 2009; van Engelsdorp et al., 2012;

210 Cavigli et al., 2016). In this study, samples from clinically healthy colonies in Serbian apiaries were analysed by real-time RT-PCR in order to detect honey bee viruses (DWV, ABPV, SBV and CBPV) and determine their prevalence patterns and prevalence. The results revealed DWV 
213 to be the most prevalent virus in Serbian apiaries, not unlike in many other countries: Hungary

214 (Bakonyi et al., 2002), France (Tentcheva et al., 2004; Mouret et al., 2013), Austria (Berenyi et

215 al., 2006), Slovenia (Toplak et al., 2012) and Uruguay (Giacobino et al., 2016). High prevalence

216 of DWV (74\%) and ABPV (49.3\%) recorded in Serbian apiaries are not surprising, knowing

217 their close relation to $V$. destructor mite infestation and their persistence as subclinical infection

218 in apparently healthy colonies (Gauthier et al., 2007; Mouret et al., 2013; Wells et al., 2016). The

219 average prevalence of SBV in Serbian samples was 24\%, and none of the investigated colonies

220 exhibited signs of sacbrood disease. The absence of disease signs in all recorded SBV-positive

221 colonies may be the result of prominent hygienic behaviour (Swanson et al., 2009), previously

222 confirmed for honey bees throughout Serbia (Stanimirović et al., 2002; Stanimirović, Stevanović

223 \& Ćirković, 2005; Stanimirović et al., 2008; Stanimirović et al., 2011). The frequency of SBV in

224 Serbia is similar with 40.24\% recorded in Croatia (TlakGajger et al., 2014), considerably lower

225 than 86\% from France (Tentcheva et al., 2004) and 100\% from Uruguay (Antúnez et al., 2006),

226 but several times higher than 1.1\%, 1.4\% and 2\% reported in Spain (Antúnez et al., 2012),

227 England (Baker \& Schroeder, 2008) and Hungary (Forgach et al., 2008), respectively. Low

228 prevalence of CBPV in the samples is typical for asymptomatic colonies (Tentcheva et al.,

229 2004). The rate of 0-19\% CBPV-positive samples affirmed in Serbia is in accordance with the

230 results obtained in the majority of Austrian federal states (Berenyi et al., 2006), Chinese

231 provinces (Ai, Yan, \& Han,., 2012), Korea (Choe et al., 2012), Slovenia (Toplak et al., 2012),

232 and the apiaries from Denmark (Nielsen, Nicolaisen \& Kryger, 2008) and France (Tentcheva et

233 al., 2004).

234 Among monitored honey bee viruses in Serbia, the highest incidence was recorded for DWV

235 (66.7-83.3\%). No significant differences in its prevalence among Serbian regions is not

236 surprising knowing its global occurrence (Wilfert et al., 2016) and its dominance over other

237 viruses in variable environmental conditions (Giacobino et al., 2016).

238 The second most common virus in Serbian apiaries was ABPV, but its incidence (16.7-68.2\%)

239 significantly varied between the regions. The prevalence of SBV and CBPV also displayed

240 dissimilar patterns in environmentally different regions. Additional investigations are necessary

241 to explain the observed significant differences. It can be assumed that these results may reflect

242 the beekeepers' negligence of apicultural measures (Stanimirovic et al., 2007a), but also may

243 have risen from different means of $V$. destructor control (Nielsen, Nicolaisen \& Kryger, 2008), 
244 which may be the reason only in ABPV infection, since not all viruses are transmitted by varroa

245 mites (Glenny et al., 2017).

246 Nevertheless, differences in orographic factors and forage quality between regions should be also

247 considered as the environment was suggested as a key factor interacting with local bee

248 populations and ecogenotypes (Stanimirović, Stevanović \& Ćirković; 2005; Giacobino et al.,

249 2016). Our results concerning $87.33 \%$ samples with at least one virus and $58.66 \%$ with two or

250 more are similar to those observed in Austria (Berenyi et al., 2006), France (Tentcheva et al.,

251 2004; Gauthier et al., 2007) and Slovenia (Toplak et al., 2012).

252 Interestingly, no significant differences were found in the presence of DWV, ABPV, SBV and

253 CBPV infections (and their combinations) in colonies of various strength. In addition, no

254 significant differences were affirmed between single DWV infection levels (expressed through a

$255 \mathrm{Ct}$ value) in colonies of different strength. These results may speak in favour of crucial influence

256 of predisposing factors - pathogens, parasites, poor-quality nutrition, pesticides, and

257 unfavourable climate conditions - on bee vitality (Stanimirović et al., 2007a; Simeunović et al.,

258 2014b, Abbo et al., 2017; Annoscia et al., 2018, Glavinic et al., 2017, Stevanović et al., 2016).

259 Special emphasis should be put on the negative influence of infestation with $V$. destructor, a

260 biological and mechanical vector of at least two viruses, DWV and APBV, (Ryabov et al., 2014;

261 Abbo et al., 2017) and a possible factor that could contribute Nosema ceranae spreading

262 (Glavinić et al., 2014;). In addition, we may assume that bees highly infected with viruses do not

263 return from the field committing "altruistic suicide" to regulate colony virus load as in cases of

$264 V$. destructor and/or N. ceranae infected bees (Kralj \& Fuchs, 2006; Higes et al., 2008). In our

265 study, the presence of another virus(es), ABPV, SBV or CBPV, in co-infections significantly

266 influenced the intensity of DWV infection. The observed differences in DWV Ct values between

267 co-infections and single DWV infections could be explained with the influence of simultaneous

268 replication of the another present virus, wherein the influence may be stimulatory or suppressive.

269 However, we should have in mind recent characterization of DWV master variants (DWV-A,

270 DWV-B, and DWV-C) and their impact on bee health (McMenamin \& Flenniken, 2018).

271 Very small percentages of multiple infections in comparison with single infections found in this

272 study point out the possibility that the former are related with severe $V$. destructor infestations

273 commonly observed in Serbian apiaries (Stanimirović et al., 2007a, 2017). 
275 High identity rates among relatively short studied nucleotide sequences of DWVs account for the 276 poorly supported and unresolved phylogenetic tree (Fig.6). However, the observed close genetic

277 distance between all DWVs is concordant with the hypothesis of their relatively recent

278 evolutionary diversification and worldwide spread, potentially connected to the geographic

279 expansion of their main vector, V. destructor (Berenyi et al., 2007; Wilfert et al., 2016). On the 280 other hand, Serbian and Hungarian ABPVs are closely related, and this may be explained by the 281 geographical vicinity and trade between beekeepers of the two countries. Both Serbian and 282 Hungarian ABPVs are relatively distant from those from the Western and Northern Europe, and 283 this finding is in accordance with the report of Bakonyi et al. (2002) that Hungarian ABPVs are 284 not closely related with Western and Northern European ABPVs. Although Serbian SBVs are closely related with SBVs from the continental Europe, further analysis, involving sequences from neighbouring countries, are required for determining whether similar separation exists with SBVs, as it has been affirmed in case of Serbian ABPV. CBPVs from Serbia, France, Belgium and Spain are monophyletic but Serbian CBPVs occupy a rather long branch indicating a nonnegligible genetic distance between Serbian and mentioned CBPVs. These findings may indicate that CBPV (which is taxonomically and genetically very different from the other three honey bee viruses analysed in this study), may have different epizootiological character, and hence, is less intensively involved in the geographical spread of honey bee virus strains (Ribière, Olivier \& Blanchard, 2010). Alternatively, unique genetic properties (higher mutation rate or segment rearrangements) may explain the genetic seclusion of the Serbian CBPVs. However, for better understanding of viral diversity in honey bee colonies, additional analyses are needed. This is in accordance with the opinion of Galbraith et al. (2018), who also emphasized the importance of virus development dynamics and its possible impact on honey bees. Studies on bee pathogens causing colony decline in Serbia were mainly focused on Nosema sp. (Stanimirović et al., 2007b; Stevanovic et al., 2011, Stevanović et al., 2013; Glavinić et al., 2014; Simeunovic et al., 2014b) and $V$. destructor (Stanimirović et al., 2002, Stanimirović, Stevanović \& Ćirković, 2005; Stanimirović et al., 2005; Stevanovic et al., 2008; Stanimirović et al., 2011; Radakovic et al., 2013; Gajic et al., 2013; Glavinić et al., 2014; Stanimirović et al., 2017) with only one study dealing with bee viruses (Simeunović et al., 2014a). Therefore, our work represents an important 
306

307

308

309

310

311

312

313

314

315

316

317

318

319

320

321

322

323

324

325

326

327

328

329

330

331

332

333

334

335

336

\section{Conclusions}

This work represents the first thorough investigation aimed at the constitution of the epidemiological baseline regarding molecular identification, prevalence patterns and prevalence of honey bee viruses in Serbia. The geographic origin and strength of honey bee colonies in Serbia proved to be insufficient to induce significant differences in the prevalence of the investigated viruses. Infection intensity of DWV presented through $\mathrm{Ct}$ value greatly depends on the presence of co-infection with other viruses. However, single ABPV, SBV and CBPV infection were not frequent enough to allow the comparison of their $\mathrm{Ct}$ values. In addition, the sequence analyses of Serbian honey bee viruses confirmed their identity and enabled an insight into their phylogenetic relationship with those found worldwide.

\section{References}

Abbo PM, Kawasaki JK., Hamilton M, Cook SC, DeGrandi-Hoffman G, Li W F, Liu J, Chen YP. 2017. Effects of Imidacloprid and Varroa destructor on survival and health of European honey bees, Apis mellifera. Insect Science 24:467-477 DOI 10.1111/1744-7917.12335.

Ai H, Yan X, Han R. 2012. Occurrence and prevalence of seven bee viruses in Apis mellifera and Apis cerana apiaries in China. Journal of Invertebrate Pathology 109:160-164 DOI 10.1016/j.jip.2011.10.006.

Annoscia D, Brown S, Di Prisco G, De Paoli E, Del Fabbro S, Zanni V, Galbraith D, Caprio E, Grozinger CM, Pennacchio F, Nazzi, F. 2018. Haemolymph removal by the parasite Varroa destructor can trigger the proliferation of the Deformed Wing Virus in mite infested bees (Apis mellifera), contributing to enhanced pathogen virulence. bioRxiv p.257667 DOI $10.1101 / 257667$.

ANSES - French Agency for Food, Environmental and Occupational Health and Safety. 2011. Screening for several honeybee viruses using PCR (in-house method) (ABPV, IAPV, KBV, DWV, SBV, BQCV, CBPV)) Available at http://www.anses.fr/en (accessed 5 July 2017). 
Antúnez K, D’Alessandro B, Corbella E, Ramallo G, Zunino P. 2006. Honeybee viruses in

Antúnez K, Anido M, Garrido-Bailon E, Botias C, Zunino P, Martínez-Salvador A, Higes M. 2012. Low prevalence of viruses in Spain during 2006 and 2007. Research in Veterinary Science 93:1441-1445 DOI 10.1016/j.rvsc.2012.03.006.

Antúnez K, Invernizzi C, Mendoza Y, Zunino P. 2016. Honeybee colony losses in Uruguay 347 during 2013-2014. Apidologie 48:364-370 DOI 10.1007/s13592-016-0482-2.

Bacandritsos N, Granato A, Budge G, Papanastasiou I, Roinioti E, Caldon M, Falcaro C, Gallina A. Mutinelli F. 2010. Sudden deaths and colony population decline in Greek honey bee colonies. Journal of Invertebrate Pathology 105:335-340 DOI 10.1016/j.jip.2010.08.004.

Baker A, Schroeder DD. 2008. Occurrence and genetic analysis of picorna-like viruses infecting worker bees of Apis mellifera L. populations in Devon, South West England. Journal of Invertebrate Pathology 98:239-242 DOI 10.1016/j.jip.2008.02.010.

Bakonyi T, Farkas R, Szendroi A, Dobos-Kovacs M, Rusvai M. 2002. Detection of acute bee paralysis virus by RT-PCR in honey bee and Varroa destructor field samples: rapid screening of representative Hungarian apiaries. Apidologie 33:63-74 DOI 10.1051/apido: 2001004. honeybee viruses in diseased Austrian apiaries. Applied and Environmental Microbiology 72:2414-2420 DOI 10.1128/AEM.72.4.2414-2420.2006.

Berenyi O, Bakonyi T, Derakhshifar I, Köglberger H, Topolska G, Ritter W, Pechhacker H, Nowotny N. 2007. Phylogenetic analysis of deformed wing virus genotypes from diverse 
367

368

369

370

371

372

373

374

375

376

377

378

379

380

381

382

383

384

385

386

387

388

389

390

391

392

393

394

395

396

397 geographic origins indicates recent global distribution of the virus. Applied and

Environmental Microbiology 73:3605-3611 DOI 10.1128/AEM.00696-07.

Blanchard P, Ribiere M, Celle O, Lallemand P, Schurr F, Olivier V, and Faucon JP. 2007.

Evaluation of a real-time two-step RT-PCR assay for quantitation of Chronic bee paralysis virus (CBPV) genome in experimentally-infected bee tissues and in life stages of a symptomatic colony. Journal of Virological Methods 141:7-13 DOI

10.1016/j.jviromet.2006.11.021.

Brodschneider R, Gray A, Adjlane N, Ballis A, Brusbardis V, Charrière JD, Chlebo R, Coffey MF, Dahle B, de Graaf DC, Dražić MM, Evans G, Fedoriak M, Forsythe I, Gregorc A, Grzęda U, Hetzroni A, Kauko L, Kristiansen P, Martikkala M, Martín-Hernández R, Medina-Flores CA, Mutinelli F, Raudmets A, Ryzhikov VA, Simon-Delso N, Stevanovic J, Uzunov A, Vejsnæs F, Wöhl S, Zammit-Mangion M, Danihlík J. 2018. Multi-country loss rates of honey bee colonies during winter 2016/2017 from the COLOSS survey. Journal of Apicultural Research 57:452-457, DOI: 10.1080/00218839.2018.1460911.

Brutscher LM, McMenamin AJ, Flenniken ML. 2016. The buzz about honey bee viruses. PLoS Pathogens 12:e1005757 DOI 10.1371/journal.ppat.1005757.

Cavigli I, Daughenbaugh KF, Martin M, Lerch M, Banner K, Garcia E, Brutscher LM, Flenniken ML. 2016. Pathogen prevalence and abundance in honey bee colonies involved in almond pollination. Apidologie 47:251-266 DOI 10.1007/s 13592-015-0395-5.

Chantawannakul P, Ward L, Boonham N, Brown M. 2006. A scientific note on the detection of honeybee viruses using real-time PCR (TaqMan) in Varroa mites collected from a Tai honeybee (Apis mellifera) apiary. Journal of Invertebrate Pathology 91:69-73 DOI 10.1016/j.jip.2005.11.001.

Chen YP, Siede R. 2007. Honey bee viruses. Advances in Virus Research 70:33-80 DOI 10.1016/S0065-3527(07)70002-7. 
Choe SE, Nguyen LTK, Noh JH, Koh HB, JeanYH, Kweon CH. Kang SW. 2012. Prevalence

400 and distribution of six bee viruses in Korean Apis cerana populations. Journal of

401 Invertebrate Pathology 109:330-333 DOI 10.1016/j.jip.2012.01.003

402

403

404

405

406

Forgách P, Bakonyi T, Tapaszti Z, Nowotny N. Rusvai M. 2008. Prevalence of pathogenic bee viruses in Hungarian apiaries: situation before joining the European Union. Journal of 407

408

409

Francis RM, Nielsen SL, Kryger P. 2013. Varroa-virus interaction in collapsing honey bee colonies. PLoS One 8:e57540 DOI 10.1371/journal.pone.0057540.

410

411

412

Gajic B, Radulovic Z, Stevanovic J, Kulisic Z, Vucicevic M, Simeunovic P, Stanimirovic Z.

413 2013. Variability of the honey bee mite Varroa destructor in Serbia, based on mtDNA analysis. Experimental and Applied Acarology 61:97-105 DOI 10.1007/s10493-013-9683-9.

Galbraith DA, Fuller, ZL, Ray AR, Brockmann A, Frazier M, Gikungu MW, Martinez FI, 420

Gauthier L, Tentcheva D, Tournaire M, Dainat B, Cousserans F, Colin ME, Bergoin M. PCR technique. Apidologie 38:426-435 DOI 10.1051/apido:2007026. 
428

429

430

431

432

433

434

435

436

437

438

439

440

441

442

443

444

445

446

447

448

449

450

451

452

453

454

455

456

457
Giacobino A, Molineri AI, Pacini A, Fondevila N, Pietronave H, Rodríguez G, Palacio A, Bulacio Cagnolo N, Orellano E, Salto CE, Signorini ML, Merke J. 2016. Varroa destructor and viruses association in honey bee colonies under different climatic conditions. Environmental Microbiology Reports 8:407-412 DOI 10.1111/1758-2229.12410.

Glavinić U, Stevanović J, Gajić B, Simeunović P, Đurić S, Vejnović B, Stanimirović Z. 2014. Nosema ceranae DNA in honey bee haemolymph and honey bee mite Varroa destructor. Acta Veterinaria-Beograd 64:349-357 DOI 10.2478/acve-2014-0033.

Glavinic U, Stankovic B, Draskovic V, Stevanovic J, Petrovic T, Lakic N Stanimirovic Z. 2017. Dietary amino acid and vitamin complex protects honey bee from immunosuppression caused by Nosema ceranae. PLoS ONE 12:e0187726 DOI 10.1371/journal.pone.0187726.

Glenny W, Cavigli I, Daughenbaugh KF, Radford R, Kegley SE, Flenniken ML. 2017. Honey bee (Apis mellifera) colony health and pathogen composition in migratory beekeeping operations involved in California almond pollination. PLoS One 12:e0182814 DOI 10.1371/journal.pone.0182814.

Goulson D, Nicholls E, Botias C, Rotheray EL. 2015. Bee declines driven by combined stress from parasites, pesticides, and lack of flowers. Science 347:1255957 DOI 10.1126/science. 1255957.

Higes M, Martín-Hernández R, Botías C, Bailón EG, González-Porto AV, Barrios L, Del Nozal MJ, Bernal JL, Jiménez JJ, Palencia PG, Meana A. 2008. How natural infection by Nosema ceranae causes honeybee colony collapse. Environmental Microbiology 10:26592669 DOI 10.1111/j.1462-2920.2008.01687.x.

Kralj J, Fuchs S. 2006. Parasitic mites influence flight duration and homing ability of infested Apis mellifera foragers. Apidologie 37:577-587 DOI 10.1051/apido:2006040. 
458 Kulhanek K, Steinhauer N, Rennich K, Caron DM, Sagili RR, Pettis JS, Ellis JD, Wilson 459 ME, Wilkes JT, Tarpy DR, Rose R, Lee K, Rangel J, vanEngelsdorp D. 2017. A national 460 survey of managed honey bee 2015-2016 annual colony losses in the USA. Journal of 461 Apicultural Research 56:328-340 DOI 10.1080/00218839.2017.1344496.

462

463

464

Kulinčević J, Ball B, Mladjan V. 1990. Viruses in honey bee colonies infested with Varroa 465

466

467

468

469 jacobsoni: first findings in Yugoslavia. Acta VeterinariaBeograd 40:37-42.

470

471

472

473

Lee K, Steinhauer N, Rennich K, Wilson ME, Tarpy DR, Caron DM, Rose R, Delaplane KS, Baylis K, Lengerich EJ., Skinner JA, Wilkes JT, Sagili R, vanEngelsdorp D. 2015. A national survey of managed honey bee 2013-2014 annual colony losses in the USA. Apidologie 46:292-305 DOI 10.1007/s13592-015-0356-Z.

474

McMenamin AJ, Genersch E. 2015. Honey bee colony losses and associated viruses. Current 477

Opinion in Insect Science 8:121-129 DOI 10.1016/j.cois.2015.01.015.

481

McMenamin AJ, Flenniken ML. 2018. Recently identified bee viruses and their impact on bee pollinators. Current Opinion in Insect Science 26:120-129 DOI 10.1016/j.cois.2018.02.009.

Mouret C, Lambert O, Piroux M, Beaudeau F, Provost B, Benet P, Colin ME, L'Hostis M. 2013. Prevalence of 12 infectious agents in field colonies of 18 apiaries in Western France. Revue de Medecine Veterinaire 164:577-582.

\section{6}

Nielsen SL, Nicolaisen M, Kryger P. 2008. Incidence of acute bee paralysis virus, black queen cell virus, chronic bee paralysis virus, deformed wing virus, Kashmir bee virus and 
488

489

490

491

492

493

494

495

496

497

498

499

500

501

502

503

504

505

506

507

508

509

510

511

512

513

514

515

516

517

sacbrood virus in honey bees (Apis mellifera) in Denmark. Apidologie 39:310-314 DOI 10.1051/apido:2008007.

Radakovic M, Stevanovic J, Djelic N, Lakic N, Knezevic-Vukcevic J, Vukovic-Gacic B, Stanimirovic Z. 2013. Evaluation of the DNA damaging effects of amitraz on human lymphocytes in the Comet assay. Journal of Biosciences 38:53-62 DOI 10.1007/s12038-0129287-2.

Ribière M1, Olivier V, Blanchard P. 2010. Chronic bee paralysis: a disease and a virus like no other? Journal of Invertebrate Pathology 103: S120-S131 DOI 10.1016/j.jip.2009.06.013.

Ryabov EV,Wood GR, Fannon JM, Moore JD, Bull JC, Chandler D, Mead A, Burroughs N, Evans JD. 2014. A virulent strain of deformed wing virus (DWV) of honeybees (Apis mellifera) prevails after Varroa destructor-mediated, or in vitro, transmission. PLoS Pathog., 10:e1004230 DOI 10.1371/journal.ppat.1004230.

Simeunović P, Stevanović J, Vidanović D, Nišavić J, Radović D, Stanišić Lj, Stanimirović Z. 2014a. A survey of deformed wing virus and acute bee paralysis virus in honey bee colonies from Serbia using real-time RT-PCR. Acta Veterinaria-Beograd 64:81-92 DOI: 10.2478/acve-2014-0009.

Simeunovic P, Stevanovic J, Cirkovic D, Radojicic S, Lakic N, Stanisic Lj, Stanimirovic Z. 2014b. Nosema ceranae and queen age influence the reproduction and productivity of the honey bee colony. Journal of Apicultural Research 53:545-554 DOI 10.3896/IBRA.1.53.5.09.

Stanimirović Z, Pejović D, Stevanović J, Vučinić M, Mirilović M. 2002. Investigations of hygienic behaviour and disease resistance in organic beekeeping of two honeybee ecogeographic varieties from Serbia. Acta Veterinaria-Beograd 52:169-180 DOI 10.2298/AVB0203169S. 
519 Stanimirović Z, Stevanović J, Ćirković D. 2005. Behavioural defenses of the honey bee

520 ecotype from Sjenica - Pester against Varroa destructor. Acta Veterinaria-Beograd 55:69-82

521 DOI 10.2298/AVB0501069S.

522

523 Stanimirovic Z, Stevanovic J, Jovanovic S, Andjelkovic M. 2005. Evaluation of genotoxic

524 effects of Apitol® (cymiazole hydrochloride) in vitro by measurement of sister chromatid

525 exchange. Mutation Research/Genetic Toxicology and Environmental Mutagenesis 588:152-

526157 DOI 10.1016/j.mrgentox.2005.10.003.

527

528 Stanimirović Z, Ćirković D, Pejin II, Pejović D. 2007a. Strategy for ecologic control in

529 fighting Varroa destructor. Veterinarski glasnik 61:11-35 [in Serbian].

530 Stanimirovic Z, Stevanovic J, Bajic V, Radovic I. 2007b. Evaluation of genotoxic effects of

531 fumagillin by cytogenetic tests in vivo. Mutation Research/Genetic Toxicology and

532 Environmental Mutagenesis 628:1-10 DOI 10.1016/j.mrgentox.2006.09.014.

533

534 Stanimirović Z, Stevanović J, Mirilović M, Stojić V. 2008. Heritability of hygienic behaviour

535 in grey honey bees (Apis mellifera carnica). Acta Veterinaria-Beograd 58:593-601 DOI

$536 \quad 10.2298 / A V B 0806593 \mathrm{~S}$.

537

538

539

540

Stanimirović Z, Aleksić N, Stevanović J, Ćirković D, Mirilović M, Djelić N,Stojić V. 2011.

The influence of pulverised sugar dusting on the degree of infestation of honey bee colonies with Varroa destructor. Acta Veterinaria-Beograd 61:309-325 DOI 10.2298/AVB1103309S.

541

542

543

544

Stanimirović Z, Glavinić U, Lakić N, Radović D, Ristanić M, Tarić E, Stevanović J. 2017.

Efficacy of plant-derived formulation “Argus Ras” in Varroa destructor control. Acta

545 
546 Steinhauer N, Kulhanek K, Antúnez K, Human H, Chantawannakul P, Chauzat MP,

547 vanEngelsdorp D. 2018. Drivers of colony losses. Current Opinion in Insect Science 26:142-

$548 \quad 148$ DOI 10.1016/j.cois.2018.02.004.

549

550 Stevanovic J, Stanimirovic Z, Radakovic M, Stojic V. 2008. In vitro evaluation of the

551 clastogenicity of fumagillin. Environmental and Molecular Mutagenesis 49:594-601 DOI

$552 \quad 10.1002 / \mathrm{em} .20409$.

553

554 Stevanovic J, Stanimirovic Z, Genersch E, Kovacevic SR, Ljubenkovic J, Radakovic M,

555 Aleksic N. 2011. Dominance of Nosema ceranae in honey bees in the Balkan countries in the

556 absence of symptoms of colony collapse disorder. Apidologie 42:49-58 DOI

557 10.1051/apido/2010034.

558

559 Stevanovic J, Simeunovic P, Gajic B, Lakic N, Radovic D, Fries I, Stanimirovic Z. 2013.

560 Characteristics of Nosema ceranae infection in Serbian honey bee colonies. Apidologie 44,

$561 \quad 522-536$ DOI 10.1007/s13592-013-0203-z.

562

563 Stevanovic J, Schwarz RS, Vejnovic B, Evans J, Irwin RE, Glavinic U, Stanimirovic Z.

564 2016. Species-specific diagnostics of Apis mellifera trypanosomatids: a nine-year survey

565 (2007-2015) for trypanosomatids and microsporidians in Serbian honey bees. Journal of

566 Invertebrate Pathology 139:6-11 DOI 10.1016/j.jip.2016.07.001.

567

568

569

570

571

572

573 Tamura K, Dudley J, Nei M, Kumar S. 2007. MEGA4: molecular evolutionary genetics

574

575 analysis (MEGA) software version 4.0. Molecular Biology and Evolution 24:1596-1599 DOI

576 
577 Tentcheva D, Gauthier L, Zappulla N, Dainat B, Cousserans F, Colin ME, Bergoin M. 2004.

578 Prevalence and seasonal variations of six bee viruses in Apis mellifera L. and Varroa

579 destructor mite populations in France. Applied and Environmental Microbiology 70:7185-

5807191 DOI 10.1128/AEM.70.12.7185-7191.2004.

581

582 Tlak Gajger I, Kolodziejek J, Bakonyi T, Nowotny N. 2014. Prevalence and distribution

583 patterns of seven different honeybee viruses in diseased colonies: a case study from Croatia.

584 Apidologie 45:701-706 DOI 10.1007/s13592-014-0287-0.

585

586

587

Tlak Gajger I, Bičak J, Belužić R. 2014. The occurence of honeybee viruses in apiaries in the

588

589

590

591

Koprivnica-Križevci district in Croatia. Veterinarski Arhiv 84:421-428.

592

593

594

595

Toplak I, Rihtarič D, Ciglenečki UJ, Hostnik P, Jenčič V, Barlič-Maganja D. 2012. Detection of six honeybee viruses in clinically affected colonies of Carniolan gray bee (Apis mellifera carnica). Slovenian Veterinary Research 49:89-96.

596

597 van Engelsdorp D, Evans JD, Saegerman C, Mullin C, Haubruge E, Nguyen BK, Frazier M, 598 Frazier J, Cox-Foster D, Chen Y, Underwood R, Tarpy DR, Pettis JS. 2009. Colony collapse 599 disorder: a descriptive study. PLOS ONE 4:e6481 DOI 10.1371/ journal.pone.0006481.

600

601 van Engelsdorp D, Caron D, Hayes J, Underwood R, Henson M. 2012. A national survey of 602 managed honey bee 2010-11 winter colony losses in the USA: results from the Bee Informed 603 Partnership. Journal of Apicultural Research 51:115-124 DOI 10.3896/IBRA.1.51.1.14.

604 
605 Venturini E, Drummond FA, Hoshide AK, Dibble AC, Stack LB. 2017. Pollination

606 reservoirs in lowbush blueberry (Ericales: Ericaceae). Journal of Economic Entomology

607 110:333-346 DOI 10.1093/jee/tow285.

608

609 Wells T, Wolf S, Nicholls E, Groll H, Lim KS, Clark SJ, Swain J, Osborne JL, Haughton AJ.

610 2016. Flight performance of actively foraging honey bees is reduced by a common pathogen.

611 Environmental Microbiology Reports 8:728-737 DOI 10.1111/1758-2229.12434.

612

613 Wilfert L, Long G, Leggett HC, Schmid-Hempel P, Butlin R, Martin SJM. Boots M. 2016.

614 Deformed wing virus is a recent global epidemic in honeybees driven by Varroa mites.

$615 \quad$ Science 351:594-597 DOI 10.1126/science.aac9976.

616

617 


\section{Figure 1}

Prevalence patterns of investigated viruses in honey bee colonies in five regions of Serbia




Figure 2

Overall prevalence of CBPV, SBV, ABPV and DWV in Serbian bees (analyzed in 150 samples)

\section{Positive samples (\%)}

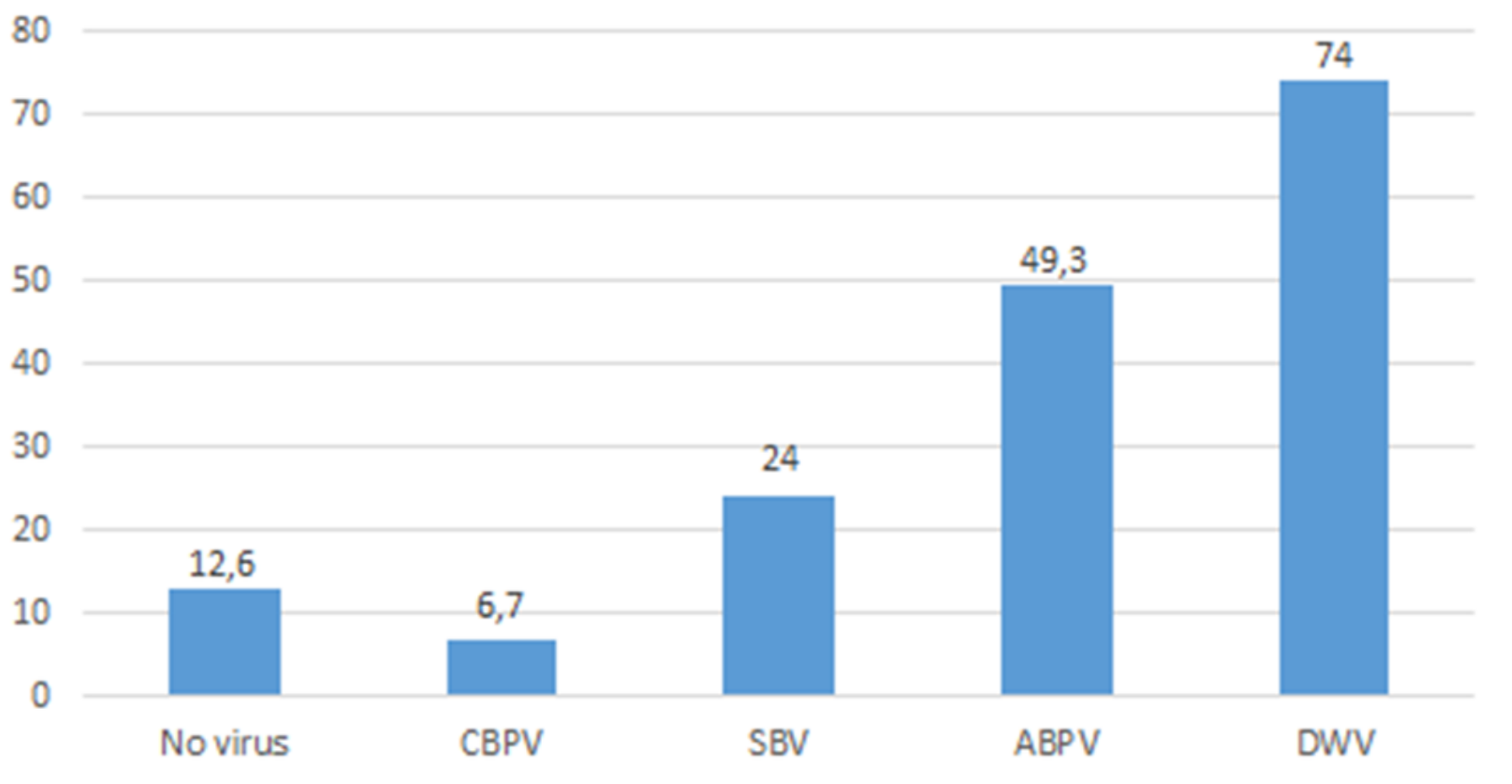


Figure 3

Prevalence of DWV, ABPV, SBV, CBPV and their combinations (A-K) in weak, medium and strong colonies

A) DWV



E)

DWV/ABPV

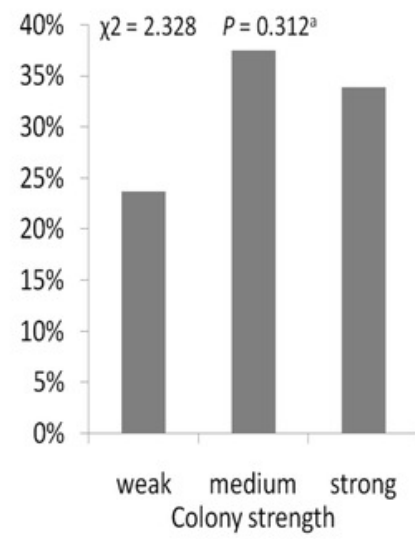

I) DWV/ABPV/CBPV



B) $A B P V$

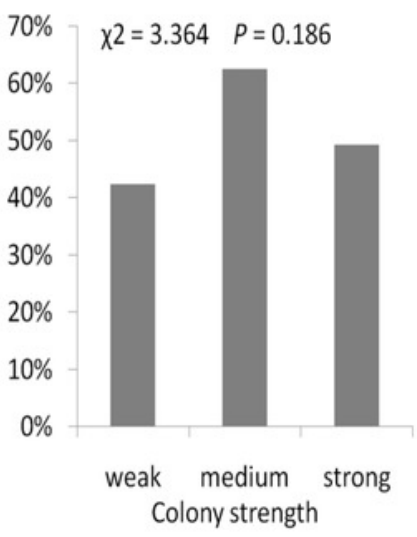

F) $\mathrm{DWV} / \mathrm{SBV}$

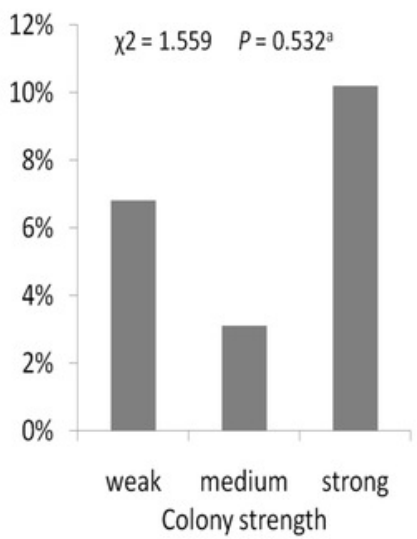

J)

DWV/ABPV/SBV



C) SBV

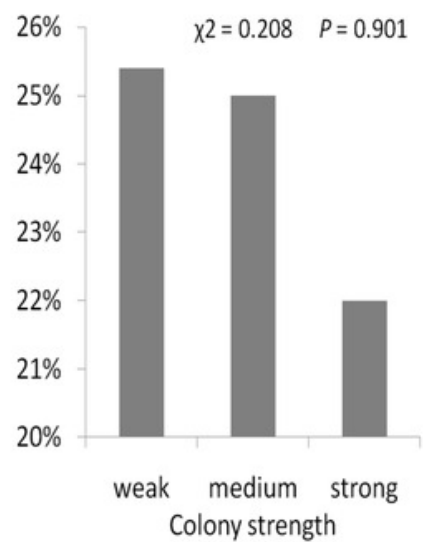

G) $\mathrm{DWV} / \mathrm{CBPV}$

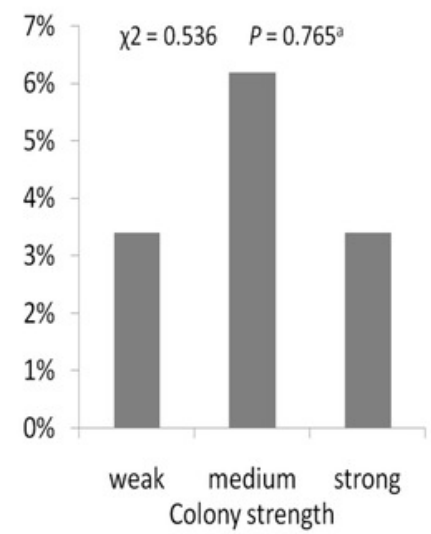

K) $\mathrm{DWV} / \mathrm{ABPV} / \mathrm{CBPV} / \mathrm{SBV}$

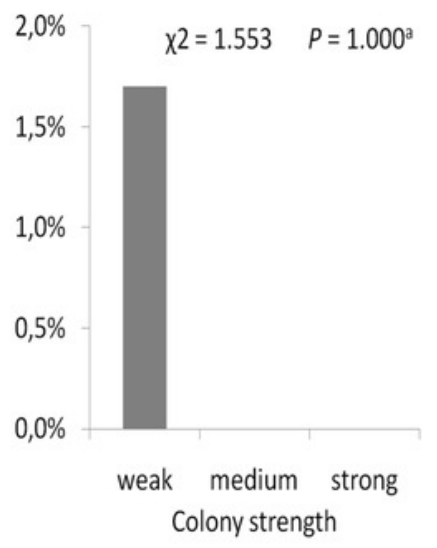

D) $\mathrm{CBPV}$



H) $\mathrm{ABPV} / \mathrm{SBV}$

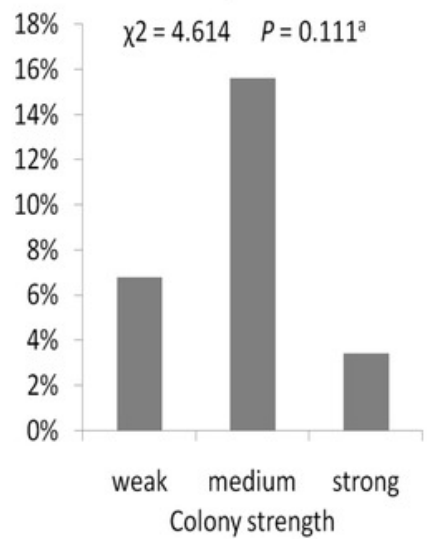


Figure 4

Intensity of DWV infection (Ct values) in weak, medium and strong colonies




Figure 5

Intensity of virus infections (Ct values) in single DWV infection and in double infections (DWV+ABPV, DWV+CBPV and DVW+SBV)






\section{Figure 6}

Neighbour-Joining tree of studied DWV sequences.

The tree was constructed using a $420 \mathrm{nt}$ long aligned matrix of 18 sequences encoding a partial coding sequence (cds) of polyprotein gene of DWVs. VDVs (AY251269 and JF440525) were used as outgroups to root the tree. Viruses are indicated with GenBank Access. Nos. and the country of origin. Numbers at nodes represent bootstrap support. Bar on the left shows the number of nucleotide substitutions per site. 


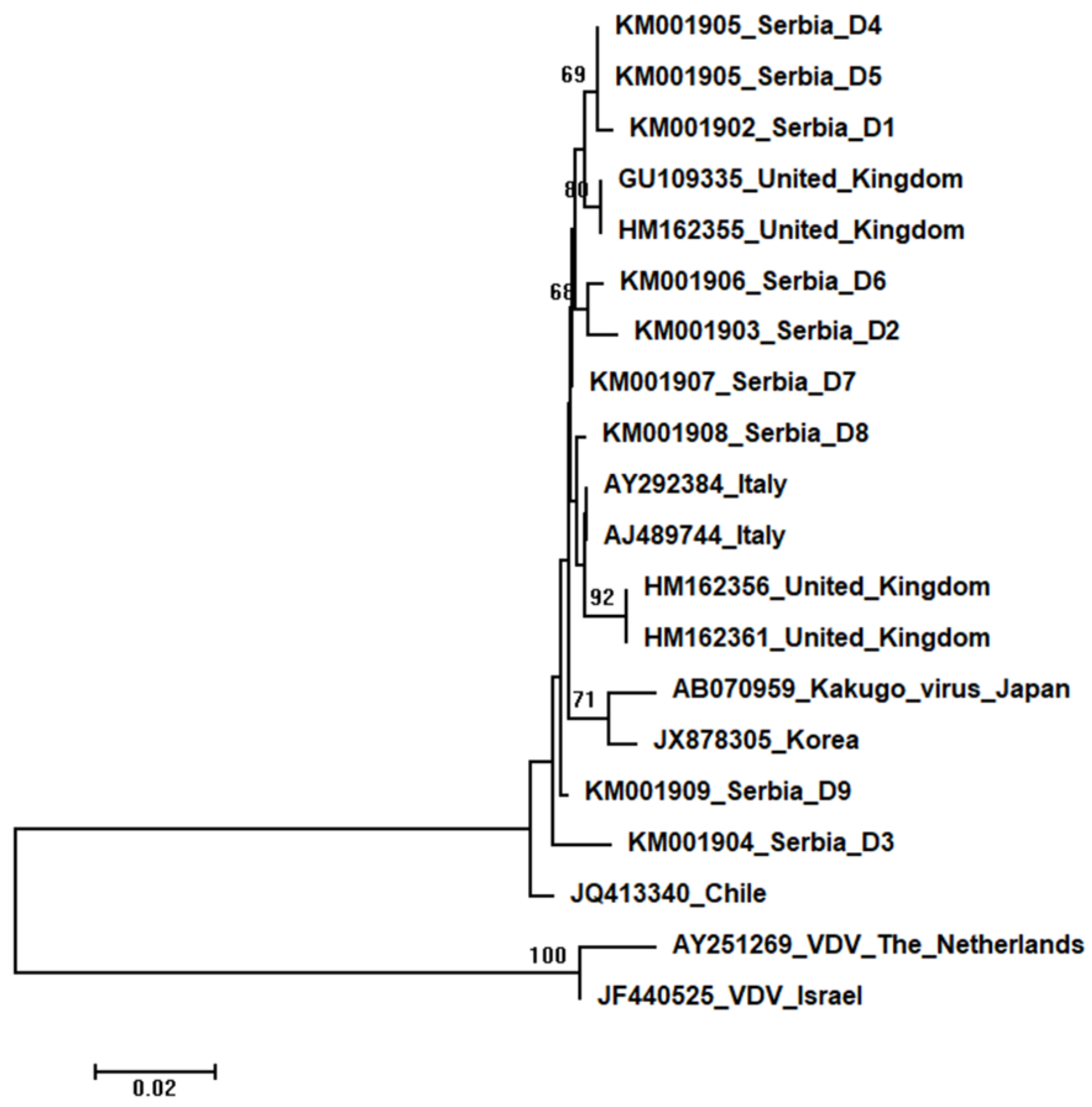




\section{Figure 7}

Neighbour-Joining tree of studied ABPV sequences.

The tree was constructed using a 398 nt long aligned matrix of 12 sequences encoding a capsid protein of ABPVs. KBV (AY452696) was used as outgroups to root the tree. Viruses are indicated with GenBank Access. Nos. and the country of origin. Numbers at nodes represent bootstrap support. Bar on the left shows the number of nucleotide substitutions per site.

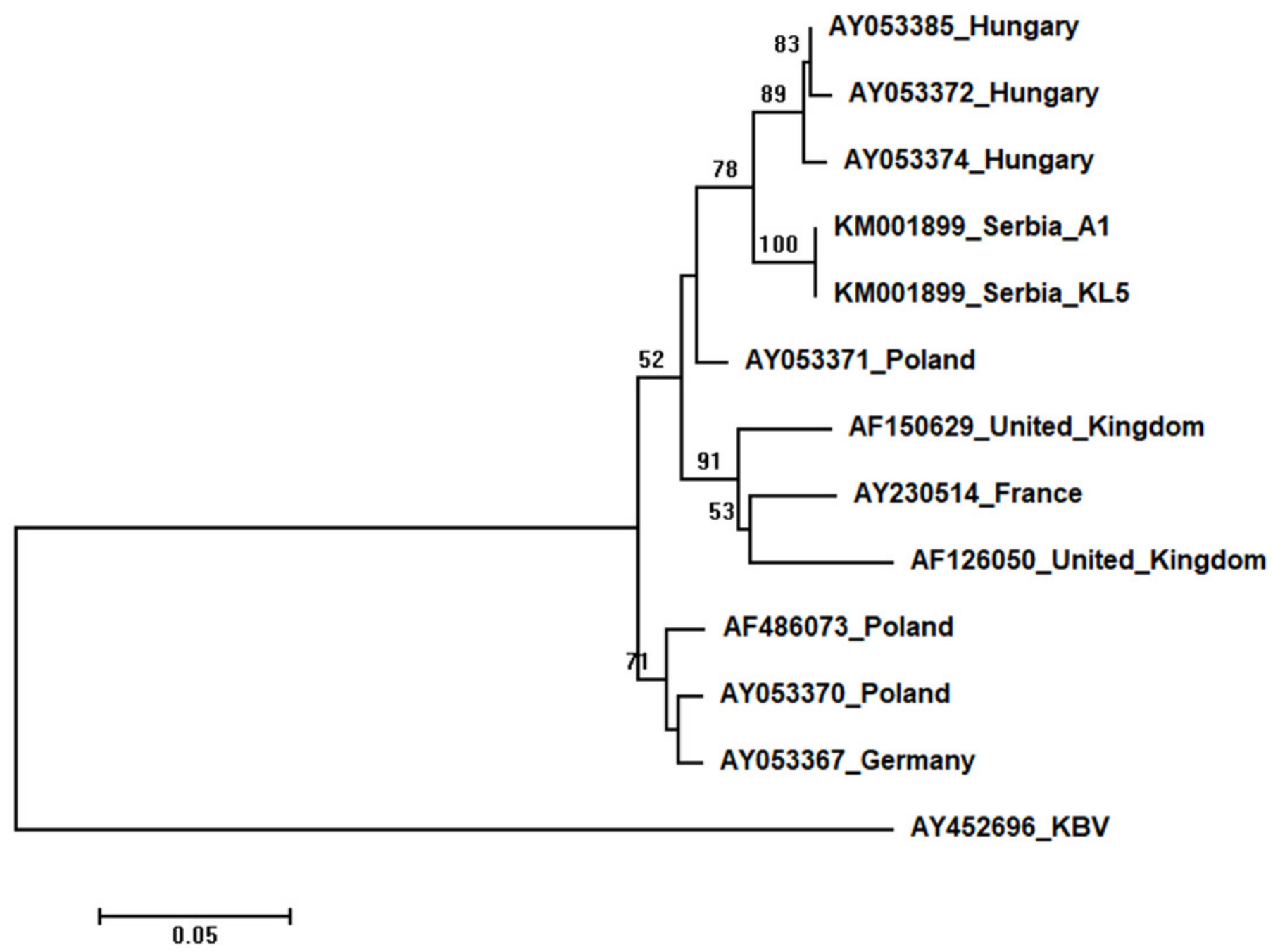




\section{Figure 8}

Neighbour-Joining tree of studied SBV sequences.

The tree was constructed using a 429 nt long aligned matrix of 20 sequences encoding a partial coding sequence (cds) of polyprotein gene of SBVs. Viruses are indicated with GenBank Access. Nos. and the country of origin. Numbers at nodes represent bootstrap support. Bar on the left shows the number of nucleotide substitutions per site






\section{Figure 9}

Neighbour-Joining tree of studied CBPV sequences.

The tree was constructed using a $570 \mathrm{nt}$ long aligned matrix of 12 sequences encoding a partial coding sequence (cds) of RNA-dependent RNA polymerase (RdRp) gene of CBPV.

FJ345326 was used as outgroup to root the tree. Viruses are indicated with GenBank Access.

Nos. and the country of origin. Numbers at nodes represent bootstrap support. Bar on the left shows the number of nucleotide substitutions per site.

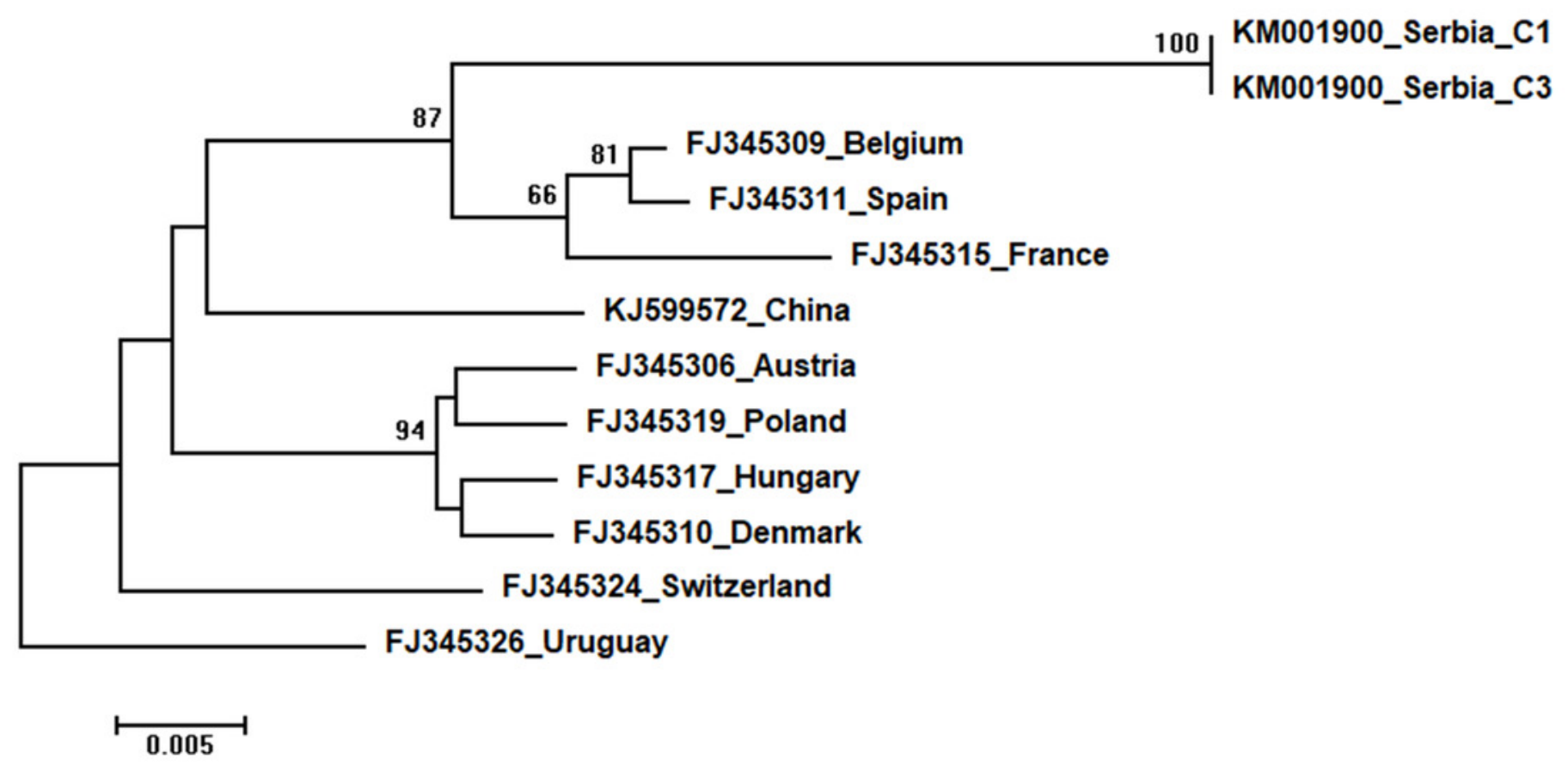




\section{Table $\mathbf{1}$ (on next page)}

Primers and probes (TaqMan Probe ${ }^{\circledR}$ ) used for RNA molecular identification of investigated viruses in real-time RT-PCR 
2 Table 1. Primers and probes (TaqMan Probe $\AA$ ) used for RNA molecular identification of

3 investigated viruses in real-time RT-PCR

\begin{tabular}{|c|c|c|c|c|}
\hline $\begin{array}{c}\text { Primer/Probe } \\
\text { name }\end{array}$ & Sequence & Primer & Virus & Primer/Probe authors \\
\hline $\begin{array}{l}\text { DWV958F } \\
\text { DWV9711R } \\
\text { DWV9627T }\end{array}$ & $\begin{array}{c}\text { 5'-AAATTCTCTCACAGTCCAAG-3', } \\
\text { 5'CAACAGGTAATTTTCCTTTAG-3', } \\
\text { 5'-CATGCTCGAGGATTGGGTCGTCGT-3' }\end{array}$ & $\begin{array}{l}\text { Forward } \\
\text { Reverese } \\
\text { Probe }\end{array}$ & $\begin{array}{l}\text { Deformed } \\
\text { Wing Virus }\end{array}$ & $\begin{array}{l}\text { Chantawannakul } \\
\text { et al., } 2006\end{array}$ \\
\hline $\begin{array}{l}\text { APV95F } \\
\text { APV159R } \\
\text { APV121T }\end{array}$ & $\begin{array}{l}\text { 5'- TCCTATATCGACGACGAAAGACAA-3' } \\
\text { 5'- GCGCTTTAATTCCATCCAATTGA-3' } \\
\text { 5'- TTTCCCCGGACTTGAC-3' }\end{array}$ & $\begin{array}{l}\text { Forward } \\
\text { Reverese } \\
\text { Probe }\end{array}$ & $\begin{array}{l}\text { Acute Bee } \\
\text { Paralysis } \\
\text { Virus }\end{array}$ & $\begin{array}{l}\text { Chantawannakul } \\
\text { et al., } 2006\end{array}$ \\
\hline $\begin{array}{l}\text { SBV311F } \\
\text { SBV380R } \\
\text { SBV331T }\end{array}$ & $\begin{array}{c}\text { 5'-AAGTTGGAGGCGCGYATTTG-3' } \\
\text { 5'-CAAATGTCTTCTTACDAGAAGYAAGGATTG- 3' } \\
\text { 5'-CGGAGTGGAAAGAT-3' }\end{array}$ & $\begin{array}{l}\text { Forward } \\
\text { Reverese } \\
\text { Probe }\end{array}$ & $\begin{array}{c}\text { Sacbrood } \\
\text { Virus }\end{array}$ & $\begin{array}{l}\text { Chantawannakul } \\
\text { et al., } 2006\end{array}$ \\
\hline $\begin{array}{l}\text { CBPV1F } \\
\text { CBPV2R } \\
\text { CBPVT }\end{array}$ & $\begin{array}{l}\text { 5'-CGCAAGTACGCCTTGATAAAGAAC-3' } \\
\text { 5'-ACTACTAGAAACTCGTCGCTTCG-3' } \\
\text { 5'-TCAAGAACGAGACCACCGCCAAGTTC-3' }\end{array}$ & $\begin{array}{l}\text { Forward } \\
\text { Reverese } \\
\text { Probe }\end{array}$ & $\begin{array}{l}\text { Chronic } \\
\text { Bee } \\
\text { Paralyses } \\
\text { Virus }\end{array}$ & Blanchard et al., 2007 \\
\hline
\end{tabular}

4 


\section{Table 2 (on next page)}

Prevalences of single and simultaneous virus infections in honey bee samples from Serbia. DWV - deformed wing virus; CBPV - chronic bee paralysis virus; ABPV - acute bee paralysis virus; SBV - sacbrood virus 
2

3 Table 2. Prevalences of single and simultaneous virus infections in honey bee samples from

4 Serbia. DWV - deformed wing virus; CBPV - chronic bee paralysis virus; ABPV - acute bee 5 paralysis virus; $\mathrm{SBV}$ - sacbrood virus

6

\begin{tabular}{|c|c|c|c|}
\hline $\begin{array}{c}\text { No. of } \\
\text { viruses in } \\
\text { simultaneous } \\
\text { infection }\end{array}$ & Type of infection & $\begin{array}{c}\text { No. of } \\
\text { samples }\end{array}$ & $\%$ \\
\hline 0 & l & 19 & 12.67 \\
\hline \multirow[t]{4}{*}{1} & DWV & 32 & 21.33 \\
\hline & ABPV & 6 & 4.00 \\
\hline & SBV & 4 & 2.67 \\
\hline & CBPV & 1 & 0.67 \\
\hline \multirow[t]{4}{*}{2} & DWV, ABPV & 44 & 29.33 \\
\hline & DWV, CBPV & 6 & 4.00 \\
\hline & DWV, SBV & 11 & 7.33 \\
\hline & $\mathrm{ABPV}, \mathrm{SBV}$ & 11 & 7.33 \\
\hline \multirow[t]{2}{*}{3} & DWV, SBV, ABPV & 12 & 8.00 \\
\hline & DWV, ABPV, CBPV & 3 & 2.00 \\
\hline 4 & $\begin{array}{l}\text { DWV, ABPV, SBV, } \\
\text { CBPV }\end{array}$ & 1 & 0.67 \\
\hline
\end{tabular}

7

8 